Научная статья

УДК 330.3

DOI 10.18101/2304-4446-2021-3-3-7

\title{
ТРУДНЫЙ ПУТЬ ВСТРАИВАНИЯ ЧЕЛОВЕЧЕСКОГО КАПИТАЛА В ПРОИЗВОДСТВЕННЫЕ ЦЕПОЧКИ ЭКОНОМИКИ
}

\author{
(C) Атанов Николай Иванович \\ доктор экономических наук, профессор, \\ Бурятский государственный университет имени Доржи Банзарова \\ Россия, 670000, г. Улан-Удэ, ул. Смолина, 24а \\ ni.atanov@yandex.ru
}

\begin{abstract}
Аннотация. Изложена точка зрения на последствия экономической реформы 1990-х гг. Причины неудач автор видит в поверхностном понимании авторами реформы сущностных характеристик рыночной модели экономики и по этой причине в смешении главных столпов с второстепенными, что привело к серьезным ошибкам, обусловившим, прежде всего, чудовищное расслоение общества, четыре финансовоэкономических кризиса и стагнацию экономического развития за последние 5 лет. Автор считает, что «душой» рыночной экономики является конкуренция, а не форма собственности, что экономика и политика неотделимы друг от друга, что двигателем современной экономики является не «физическая сила» природных и трудовых ресурсов, а «мягкая, умная сила» человеческого капитала и качественные институты, способствующие максимальному раскрытию человеческого капитала - необходимому условию перехода к постиндустриальному экономическому укладу страны.

Ключевые слова: человеческий капитал, институты, образование, инновации, научно-производственная экосистема
\end{abstract}

\section{Для цитирования}

Атанов Н. И. Трудный путь встраивания человеческого капитала в производственные цепочки экономики // Вестник Бурятского государственного университета. Экономика и менеджмент. 2021. № 3. С. 3-7.

Вектор экономической реформы России в 90-е гг. XX в., как известно, отталкивался от отрицания социалистических производственных отношений и планово-централизованной диктатуры в сторону построения рыночной экономики и капиталистических производственных отношений.

О результатах реформы можно судить по четырем финансово-экономическим кризисам в промежутке 30 лет и затянувшейся стагнации за последние 5 лет с признаками позднесоветского застоя.

В чем причины неудач реформы, приведшие к чудовищному расслоению общества на богатых и сверхбогатых — на одном полюсе и на обширный слой населения с низкими доходами - на другом?

Какая невидимая идеологическая «мина замедленного действия» была изначально заложена под фундамент новой экономической доктрины, вследствие которой нынешний режим проявляет неспособность ответить на главные вызовы формирующейся постиндустриальной эпохи? 
Как так сложилось, что системноцентричные задачи производственного инновационного развития экономики, декларируемые в посланиях и указах президента страны, хронически не выполняются?

Почему значительная часть народонаселения страны не чувствует своего потенциала, не видит привлекательных, захватывающих дух ориентиров и не ставит перед собой большие цели, а находится под гнетом сиюминутных и текущих задач и дел?

Сколько лет еще протянет модель национальной экономики, базирующаяся на эксплуатации «физической силы» природных и трудовых ресурсов, хотя повестка ее перезагрузки на «умную и мягкую силу» человеческих знаний вручена без малого 20 лет назад?

Без представления об этих фундаментальных вещах невозможно построить эффективную и экономически устойчивую модель экономического и социального устройства, раскрепостить и вздыбить общественные производительные силы страны, открыть шлюзы для инициативы, смекалки, трудолюбия, знаний и энтузиазма народа. У Стефана Цвейга есть замечательное высказывание: «Когда отдельный человек или народ дерзает взять на себя задачу, превышающую его силы, силы эти возрастают до неслыханных размеров» $[1$, с. 5$]$.

Рассмотрим исходные основополагающие условия нормального функционирования рыночной экономики, нарушение которых оборачивается для народонаселения России перманентными проблемами.

\section{1. «Душа» рыночной экономики в конкуренции}

Капиталистический дух таится не столько в частной собственности, рыночном обмене и самих бизнесменах, сколько в свободном доступе к конкуренции. Если рыночная экономика строится в интересах капиталистов, то ее следствием становится экономическая неэффективность и социальная несправедливость. Столкнувшись с коррумпированным капитализмом, народ выбирает социализм. Нужно защищать капитализм, а не капиталистов, рынки, а не крупных игроков на нем. В противном случае олигархи, объединившись с теми, кто боится конкуренции, могут затормозить развитие рынков в своих интересах. Итог - торжество «капитализма для своих».

Под предлогом спасения страны от внешних угроз, социальной защиты бедных слоев населения от инфляции, поддержания платежеспособного спроса и т. д. политикам и чиновникам легко отказаться от правил добросовестной конкуренции. В таком случае институты управления отступают в своих позициях родственным, дружеским связям и другим неформальным действиям.

\section{2. Хорошая экономика неотделима от хорошей политики}

Когда в стране доминирует взвешенная политика, не отданная на аутсорсинг частным интересам, тогда и институты управления развитием работают исправно.

Предотвратить дальнейший рост социальной поляризации общества можно не только инструментами монетарно-фискальной политики, но и политикой по сокращению неравенства в доступе к улучшению человеческого капитала, прежде всего, путем увеличения бюджетных мест в учебных учреждениях, повышения качества образования, престижа и статуса учителей и ученых на основе создания карьерных стимулов, кратного увеличения их денежного содержания. «Отношение к учителю, считал первый канцлер Германии Отто фон Бисмарк, - есть 
Н. И. Атанов. Трудный путь встраивания человеческого капитала в производственные цепочки экономики

государственная политика. Она свидетельствует либо о силе государства, либо о его слабости» ${ }^{1}$. В аналогичных действиях со стороны государства нуждается вся социальная среда. Особого внимания требуют к себе бедные семьи, их дети для получения ими общего и третичного образования. Миссия оказалась невыполнимой из-за разобщенности воспроизводственных цепочек между фундаментальной наукой, НИОКР и производством, несостоятельности институтов управления в создании единой научно-производственной экосистемы. По этой же причине не выполнена Стратегия инновационного развития Российской Федерации на период до 2020 года (Распоряжение Правительства РФ от 8 декабря 2011 года № 2227-p) ${ }^{2}$.

Российский социум исторически верит в творение чудес. В 1990-е гг. ждали чуда от приватизации, а получили олигархат. В нулевые годы мыслили себя энергетической сверхдержавой, прозевав при этом технологическую революцию в мировой энергетике. После присоединения Крыма ожидали чуда от импортозамещения, которое обернулось усилением санкционного давления.

Теперь нарастает ожидание очередного чуда от человеческого капитала и его производных - цифровых технологий.

\section{3. Какая политика поможет человеческому капиталу реализоваться по максимуму?}

Развитие общества находится в зависимости от базовых факторов: что народонаселение знает и умеет (человеческий капитал) и как оно взаимодействует друг с другом (институты).

Россия в пятерке стран лидеров по наличию человеческого капитала. Умение эффективно управлять и использовать его не менее важно, чем его наличие. В современном мире те, кто умеет производить и обладать новейшими знаниями и лучше других ими распоряжаться, получают огромные экономические и политические дивиденды.

Но человеческий капитал воплощен в людях, каждый из которых индивидуален в своих устремлениях, интересах и производительности, и не факт, что они совпадают с представлениями органов управления.

Человеческий капитал и институты функционируют взаимозависимо. Поэтому задача институтов - стремиться к балансу между спросом и предложением на человеческий капитал. Пока же превалирует дисбаланс между спросом организаций и предложениями высших и средних профессиональных образовательных учреждений в регионах.

Нормативное правовое регулирование данного вопроса предполагает принятие федерального закона «Развитие персонала организаций», в котором следует прописать нормы финансирования на обучение и переобучение кадров. Договоры между организациями и профессиональными учебными заведениями являлись бы основой для включения затрат на обучение в себестоимость продукции. Положительные последствия от принятия закона мультипликативны. Подготовка человеческого капитала приняла бы целевой характер и стала практикоориенти-

\footnotetext{
${ }^{1}$ Яндекс. 3citaty.ru (дата обращения: 21.07.2021).

${ }^{2}$ Стратегия инновационного развития Российской Федерации на период 2020 г.: распоряжение Правительства РФ от 08.12.2011 № 2227-p. URL: www.consultant.ru (дата обращения: 28.07.2021).
} 
рованной на будущую трудовую деятельность студентов и учащихся, решалась бы проблема прохождения производственных и преддипломных практик, до $30 \%$ от учебных планов стали бы целевыми курсами по выбору, исходя из желаний обучающихся и руководства организаций.

Социальный эффект состоит в том, что снялась бы финансовая нагрузка на обучение детей с семейного бюджета, произошел бы транзит конкурса среди абитуриентов с учебного заведения на организацию-заказчика. Но главным призом является смягчение проблемы структурной безработицы, миграции молодежи из регионов в крупные агломерации России и зарубежные страны. Вузы и ссузы получили бы возможности кооперации с реальным сектором экономики и в подготовке, переподготовке, повышении квалификации кадров и в развитии научно-исследовательских работ по заказу.

Вопросы повышения качества отечественной системы образования - это большая, сложная и наиважнейшая тема для самостоятельного исследования.

Создание научно-производственно-образовательной экосистемы апробировано и показало свою высокую результативность в оборонном комплексе страны. В нем была введена плановая система, и она, как мы видим, сработала. Следовательно, сработает и в других секторах экономики, особенно на цифровой платформе.

Литература

1. Цвейг С. Подвиг Магеллана. Москва: Ломоносовъ, 2012. 240 с. Текст: непосредственный.

Статья поступила в редакиию 29.07.2021; одобрена после рецензирования 30.07.2021; принята к публикащии 18.08.2021.

\title{
A HARD WAY OF HUMAN CAPITAL INTEGRATION INTO PRODUCTION CHAINS OF THE ECONOMY
}

\author{
Nikolay I. Atanov \\ Dr. Sci. (Econ.), Prof., \\ Dorzhi Banzarov Buryat State University \\ 24a Smolina St., Ulan-Ude 670000, Russia \\ ni.atanov@yandex.ru
}

Abstract. The article presents an outlook on the consequences of the economic reform of the 1990s. We see the reasons for its failure in the superficial understanding by the authors of the reform of the essential characteristics of the economy's market model, and, the subsequent confounding of key pillars with secondary ones, which led to serious mistakes, first of all, the monstrous stratification of society, four financial and economic crises, and stagnation of economic development in last 5 years. We believe that the "soul" of the market economy is competition, not the form of ownership, that the economy and policy are inseparable from each other, that the engine of the modern economy is not a "physical force" of natural and labour resources, but a "soft, smart power" of human capital, as well as the institutions that contribute to the maximum fulfilment of human capital. All this is a prerequisite for the transition to the post-industrial economy in the country.

Keywords: human capital, institutions, education, innovations, scientific and industrial ecosystem 
Н. И. Атанов. Трудный путь встраивания человеческого капитала в производственные цепочки экономики

For citation

Atanov N. I. A Hard Way of Human Capital Integration into Production Chains of the Economy. Bulletin of Buryat State University. Economy and Management. 2021; 3: 3-7 (In Russ.).

The article was submitted 29.07.2021; approved after reviewing 30.07.2021; accepted for publication 18.08.2021. 